Dialectologia 18 (2017), 43-72.

ISSN: 2013-2247

Received 8 June 2015.

Accepted 12 October 2015.

\title{
CASE VARIATION IN UNSTRESSED THIRD PERSON PRONOUNS IN THE LINGUISTIC ATLAS OF THE IBERIAN PENINSULA
}

\author{
Olga LEÓN ZURDO \\ Universidad Autónoma de Madrid* \\ olga.leon@uam.es
}

\begin{abstract}
The aim of this work is to describe the geographic distribution of unstressed third person pronouns in Peninsular Spanish in two data sets: those coming from the Linguistic Atlas of the Iberian Peninsula (ALPI), which was compiled in the 1930s, and those originated for the Audible Corpus of Rural Spoken Spanish (COSER), sixty years later. The purpose is to determine whether the dialect areas concerning $3^{\text {rd }}$ person clitics have change along time and to analyze whether the two data sets match or not. The result shows that the dialect areas have been stable during the $20^{\text {th }}$ century, with some minor exceptions.
\end{abstract}

\section{Keywords}

third person pronouns, leísmo, laísmo, loísmo, dialectal áreas, Linguistic Atlas of the Iberian Peninsula

\section{VARIACIÓN DE CASO EN LOS PRONOMBRES ÁTONOS DE TERCERA PERSONA EN EL ATLAS LINGÜÍSTICO DE LA PENÍNSULA IBÉRICA}

\section{Resumen}

El objetivo de este trabajo es describir la distribución geográfica de los pronombres átonos de tercera persona en el español peninsular en dos conjuntos de datos: los procedentes del Atlas Lingüístico de la

\footnotetext{
* Departamento de Filología Española, Módulo IV, Facultad de Filosofía y Letras, Universidad Autónoma de Madrid, Campus de Cantoblanco, 28049 Madrid.
} 
Península Ibérica (ALPI), compilados en la década de 1930, y los originados para el Corpus Oral y Sonoro del Español Rural (COSER), sesenta años después. El objetivo es determinar si las áreas dialectales referentes a los clíticos de tercera persona sufren algún cambio a lo largo del tiempo y analizar la coincidencia de ambos grupos de datos. El resultado muestra que las áreas dialectales han se han mantenido estables a lo largo del siglo XX, con algunas variaciones menores.

Palabras clave

pronombres átonos de tercera persona, leísmo, laísmo, loísmo, áreas dialectales, Atlas Lingüístico de la Península Ibérica

\section{Introduction}

Variation in the use of unstressed pronouns in the Iberian Peninsula has aroused the interest of many specialists. There is not only a need to elucidate what caused the appearance of leísmo, laísmo and loísmo phenomena, but also a desire to describe its current geographical distribution. In relation to this, the works of Fernández-Ordóñez (1994 and 1999) stand out in the Corpus Oral y Sonoro del Español Rural 'Audible Corpus of Rural Spoken Spanish' (henceforth COSER), whose data came from surveys done in the 1990s. The aim of this work is to corroborate unpublished data collected in the 1930s by the Atlas Lingüístico de la Península Ibérica 'Linguistic Atlas of the Iberian Peninsula' (henceforth ALPI) along with results of the investigation of the COSER. Hereto, this paper has three purposes: 1 ) to determine if dialectal borders match to each other or there is a variation among them; that is, if the usage of unstressed third person pronouns has changed during the 20th century or it has been stable; 2) to analyze if ALPI data agrees with different pronominal paradigms or systems described at the end of the 1990s, and 3) to consider whether the data collecting methodology may or may not explain the potential differences: ALPI does geolinguistics surveys with induced questions and COSER semi-spontaneous interviews. 


\section{Current state of the issue}

Many authors have provided new information to the investigation of leismo, laísmo and loísmo phenomena from diachronic and synchronic perspectives. In relation to the dialectal analysis, the most exhaustive studies are those of Fernández-Ordóñez (1993, 1994, 1999 and 2001) and Klein-Andreu (1981 and 2000). Although these proposals have similar methodologies, the studies of Fernández-Ordóñez present a wider approach from a geographical point of view. This perspective is followed in this paper. ${ }^{1}$

The unstressed third person accusative forms $-l o, l a, l o-$ derive from the Latin accusative forms ILLUM, ILLAM, ILLUD; Spanish pronoun le comes from the dative form ILLI. Using these unstressed forms with the Latin values is known as "etymological uses" or case-distinguishing usage: $l o(s)$ and $l a(s)$ with masculine and feminine accusative, respectively, lo with neuter accusative and le(s) with masculine, feminine or neuter dative. However, the Spanish language presents a pronominal selection criterion different from the Latin one. This is known as leísmo, laísmo and loísmo.

Leísmo is the usage of the pronoun le instead of lo or la as a direct object. There are four types of leísmo: 1 ) personal masculine direct object ( $A$ Luis le premiaron por el esfuerzo 'Luis was rewarded for his effort'); 2) direct object of a masculine thing (Tira el jarrón porque María le ha roto 'Throw the vase away because María has broken it'); 3) plural leísmo (Los geranios les he comprado ayer 'I bought the geraniums yesterday'); and 4) feminine leísmo ( $A$ María le lleva su madre 'María is given a lift by her mother'). The less frequent phenomena are: laismo - the usage of the pronoun la instead of le as indirect object with a feminine referent ( $A$ María dila que venga 'Tell María to come') and loísmo - the usage of the pronoun lo instead of $l e$ as the dative with a masculine or neuter referent (A los niños ponlos el pañal / No lo doy importancia a eso 'Put the diaper on the children' / 'I don't care about that').

Some geographical areas can distinguish case, but accept some leísmo use. Therefore some cases of leísmo can be found in those territories, but not laísmo o

\footnotetext{
${ }^{1}$ See Fernández-Ordóñez (1999) for detailed information about pronominal systems. Also, see Gómez Seibane (2012) to learn about her synthesis on pronominal variation phenomena.
} 
loísmo. There are different situations that may have been labeled as leísmo in casedistinguishing areas. Firstly, some verbs or grammatical constructions present accusative and dative alternation, such as ayudar 'to help', Ilamar 'to call' or verbs of psychological affection. It is a "false leísmo" because speakers can distinguish between dative and accusative case; they just assign those cases to certain verbs or structures depending on the syntactic configuration of verbs or the geographical area. Secondly, those areas can also use the "courtesy leismo", which is the usage of the pronoun le as the third person pronoun usted to express respect. Thirdly, a genuine masculine personal leísmo may appear among educated speakers and writers of case-distinguishing regions in order to adjust to the Iberian Peninsula standard language.

Fernández-Ordóñez (1999) describes several pronominal systems out of the etymological area in which speakers select unstressed third person pronouns depending not only on the case, but also on other grammatical categories, such as gender, animacy or a mass/count distinction. In relation to that, the pronominal system in Basque Spanish (the Romance language in contact with Basque) uses le(s) for animate indirect and direct object, especially for person, regardless of masculine or feminine gender. Although the usage of $I O(s)$ and $l a(s)$ is higher in speakers with great knowledge of Spanish, clitics are normally omitted for inanimate direct objects. Therefore, leísmo corresponds to animacy in this category and it is not restricted by the antecedent's gender.

The Spanish pronominal system of Asturias is similar to the "etymological system", although accusative clitic selection is subject to the mass/count distinction. Thus, accusative clitic 10 is used with a mass masculine and feminine referent. However, lu-lo is used for a count masculine referent and la-las for the feminine one; dative is always $l e(s)$. There is not any pronominal syncretism or leismo in this system. Instead, although the Cantabrian Spanish pronominal system has similarities with the Asturian Spanish one, it uses the pronoun le for singular masculine accusative of countable nouns. For this reason, it is normal to have singular masculine leismo (of person and "thing") in this category.

Finally, the Castilian Spanish referential system distinguishes between mass and count referents too, but it tends to favor the usage of accusative pronouns by 
eliminating the category of case. The count pronoun $l e, l a(s)$ and the mass pronoun $l o$ are both used for accusative and dative. Fernández-Ordóñez points out three internal areas in the referential system based on which plural masculine accusative and dative pronoun is selected: les is preferred over los (system A: east of León, Palencia, northwest of Burgos and Valladolid); los is preferred over les (system B: east of Salamanca, Ávila, east of Cáceres, west of Toledo and Madrid), or the coexistence of both pronouns (system C: east and south of Burgos, south of Valladolid, north central Segovia, and west of Soria).

The variable selection of these pronouns (les or los) is explained by different factors: on the one hand, the analogy with plural forms ellos-estos-esos-aquellos 'themthese-those-those' helps to select pronoun los; on the other hand, the pronoun les is the most logical option within the referential system, because the pronoun le is always used as accusative and dative with singular masculine referents. Thus, the referential system shows masculine leísmo (person and "thing", singular and plural), laísmo (singular and plural) and loísmo (plural and neuter).

In addition, Fernández-Ordóñez $(1994,2001)$ talks about two transition systems. On the one side, an occidental transition system in the east of León, between Torío and Esla rivers, and Cea river. In this area, referential usage competes with etymological values for count and mass entities. On the other side, there is a southeastern transition system, which includes the northwestern corner of Ciudad Real, the east of Toledo and the west of Guadalajara. This area greatly corresponds with the "etymological" system, but the pronoun le is also used for count masculine accusative. ${ }^{2}$

Geographical distribution of these systems can be analyzed with the map below (extracted from Fernández-Ordóñez 2012: 81):

\footnotetext{
${ }^{2}$ Fernández-Ordóñez (1999) also talks about a standard pronominal system used by speakers of a high sociocultural level. It chooses pronouns depending on the case, with the exception of the person singular masculine accusative, which selects pronoun le.
} 


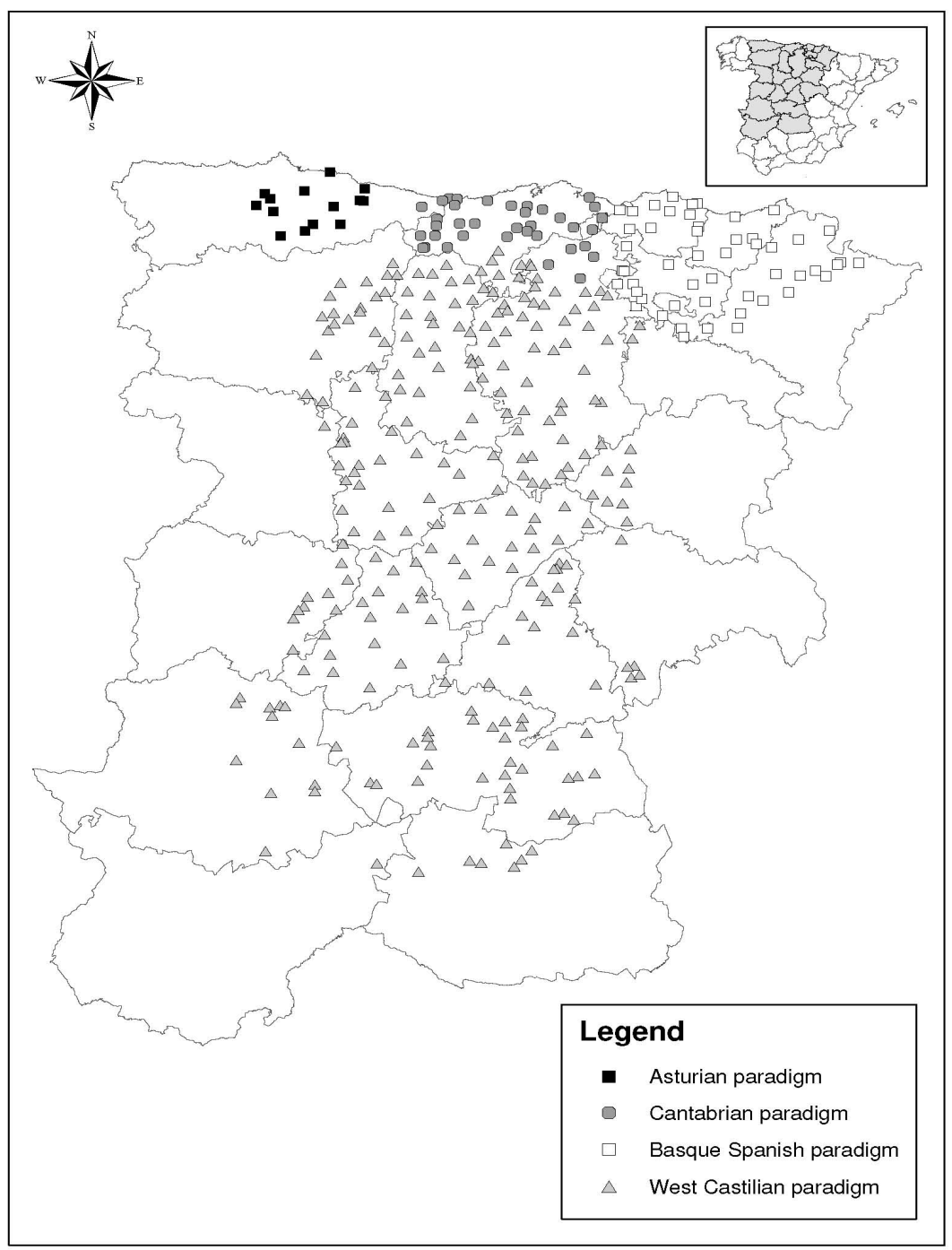

\section{Corpus and methodology}

ALPI is the corpus used as database in this paper. It was headed by Tomás Navarro Tomás in the 1930s. ALPI collected dialectal samples from all the Romance language varieties in the Iberian Peninsula and Balearic Islands with a geolinguistic questionnaire technique during the 1930s (most of them between 1931 and 1936). ALPI original notebooks disappeared around 1960s after the publication of one volume in 1962; those notebooks have seen the light again in the beginning of the 21 st century. ${ }^{3}$ Due to that, I am going to examine all data available now and link them to the COSER results in order

\footnotetext{
${ }^{3}$ See Navarro Tomás (1962), García Mouton (2009) and Heap (2003) for more information about ALPI origins, history and current projects.
} 
to determine if the linguistic borders - that Fernández-Ordóñez indicated in the 1990s - correspond to the data collected in the ALPI. ${ }^{4}$

Despite the different methodologies of data gathering, the results of ALPI and COSER can be compared because they share the same kind of participants: people from rural areas, with limited education and non-mobile. ${ }^{5}$ However, they disagree with the age of participants; ALPI uses middle age adults, but COSER only elderly people. They have different methodologies to obtain data as well. ALPI interviews participants with its own investigators' questions - which is far from being spontaneous talking and may affect the speakers' answers - whereas COSER has a sociolinguistic methodology that had still not been developed in the 1930s-40s when the majority of ALPI interviews were made. In COSER, questionnaires are replaced by semi-structured interviews; answers are less comparable than in an atlas, but they are more spontaneous. Nevertheless, I have chosen twelve questions from the first notebook of the ALPI questionnaire, in which unstressed third person pronouns appear. I will present all the results with maps in order to collate them with those obtained in the COSER.

The selected sentences are the following: (280) A ninguna le gusta ponerse la ropa de otra 'No girl likes to wear another's clothes'; (313) No lo vacíes en la calle 'Don't empty it into the street'; (350) A Miguel le cogieron preso 'Miguel was held prisoner'; (351) Le llevaron a la cárcel 'He was taken to jail'; (352) Al padre le vieron llorando 'The father was seen crying'; (353) A los niños les socorrieron los vecinos 'The children were helped by the neighbors'; (354) Me pidieron que les ayudase 'They asked me to help them'; (356) Al niño le pusieron un vestido 'The kid was made to wear a dress'; (357) Trae los candiles para echarles aceite 'Bring the oil lamps to oil them'; (359) A la madre le dieron la limosna 'The mother was given the alms'; (360) Aquella desgracia le costó la vida 'That misfortune cost her her life'; (361) A las hermanas les mandaron una carta 'The sisters were sent a letter'.

As it can be appreciated in the analysis, I differentiate between the following labels in the maps: 1) dative, 2) accusative, 3) apocope - this category gathers

\footnotetext{
${ }^{4}$ Since this paper studies the Spanish unstressed third person pronominal system, only ALPI data about Castilian Spanish areas has been used (not the Galician-Portuguese and Catalonian territories).

${ }^{5}$ Previously, Rosés Labrada (2012) carried out a similar study but limited to Zamora province and he found correspondence between ALPI and COSER data.
} 
shortened pronouns whose case cannot be determined, such as $A$ ninguna l'agrada ponerse la ropa de otra - 4) lack of pronoun - examples where any clitics have been selected, such as A ninguna agrada ponerse la ropa de otra -, and 5) dative/accusative - if the participant accepts both uses in the sentence. ${ }^{6}$

\section{Maps and presentation of results}

4.1 A ninguna le gusta ponerse la ropa de otra 'No girl likes to wear another's clothes'

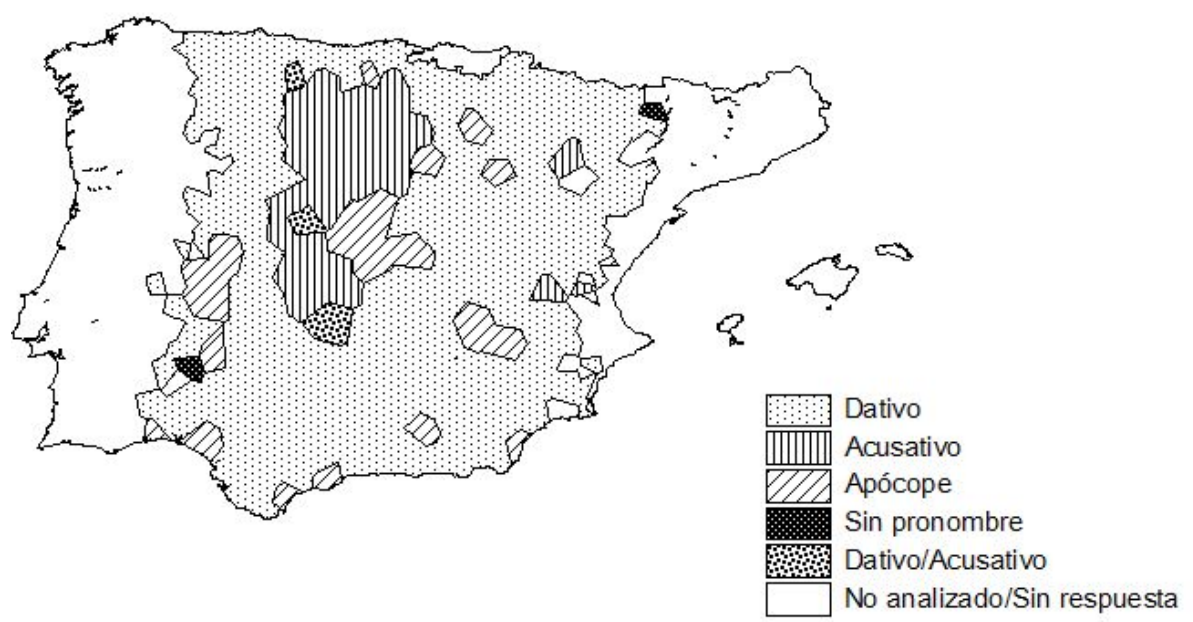

Map 1. A ninguna le gusta ponerse la ropa de otra 'No girl likes to wear another's clothes'

Two big areas are observed according to the case used in the third person pronominal unstressed reference (dative or accusative), as well as isolated enclaves that present some features related to the bordering zones.

First of all, the main verb of the sentence, gustar 'to like', selects the dative case, which means that the pronoun that corresponds etymologically to this context is the indirect object le. In the light of the obtained results, the pronominal syncretism, due to the use of the feminine singular accusative pronoun, can be seen in the Castilian provinces of Burgos, Valladolid, Palencia, Ávila and Segovia, and it also affects the

\footnotetext{
${ }^{6}$ I have not included the different phonetic variants of each pronoun because the goal of this study is to determine the selection of case.
} 
eastern sides of León, Zamora, Salamanca, Cáceres and Badajoz. Additionally, in the territory of La Mancha, this variation is practically present in all the region of Toledo, extending to the north of Ciudad Real.

Furthermore, as can be seen in the map, there are three localities (Cofiñal, in León; Grajos, in Ávila; and Puebla de Don Rodrigo, in Ciudad Real) where the informant accepts both solutions as valid.

The present data in the ALPI largely correspond to the ones extracted afterwards by Fernández-Ordóñez:

We can find usages adjusted to the patterns of the referential system in a broad peninsular area which includes territories from the west and center of Castilla, in the south of the Cantabrian Mountains reaching the limits of La Mancha [...] east of León, Palencia, Valladolid, Burgos, the western end of La Rioja, the eastern strip of Salamanca, Ávila, Segovia, west of Soria, the eastern half of Cáceres, Toledo, except the southeastern zone, Madrid and the western end of Guadalajara (1999: 1363-1364).

Stranger still is the presence of the accusative in non-referential areas such as Cadrete (Zaragoza) or Caudete de las Fuentes and Pedralba (Valencia). However, the use of the accusative in the Valencia region is justified because a change of verb was produced in the answers: instead of gustar, agradar 'to please' ( $A$ ninguna los [them.AC.MASC.PL] agrada ponerse la ropa de otra). This use could correspond to a transfer from Catalan, a language in which the plural dative els, -los, - $-l s$ is identical to the masculine plural accusative. On the other hand, in the case of Cadrete, the used verb is still gustar, so it is more difficult to determine the reasons for which the informant prefers the accusative to the dative in a zone where the pronominal uses are established on the basis of the case differentiation.

Furthermore, there are some localities in which the final vowel is shortened; therefore, it is not possible to determine the underlying pronoun. The peculiarity of all these cases is that the verb used by the informant is agradar instead of gustar, since the shortened form is a consequence of the contact between two vowels: that of the 
pronoun $(/ a / l e)$ and that of the verb agradar. Although this is a characteristic phenomenon of oral speech and, consequently, of all the Peninsular geography, the most ambiguous cases are the ones offered by Las Navas del Marqués (Ávila), Cadalso de los Vidrios (Madrid) and Rascafría (Madrid), because they are located within the referential area.

\subsection{A Miguel le cogieron preso 'Miguel was held prisoner'}

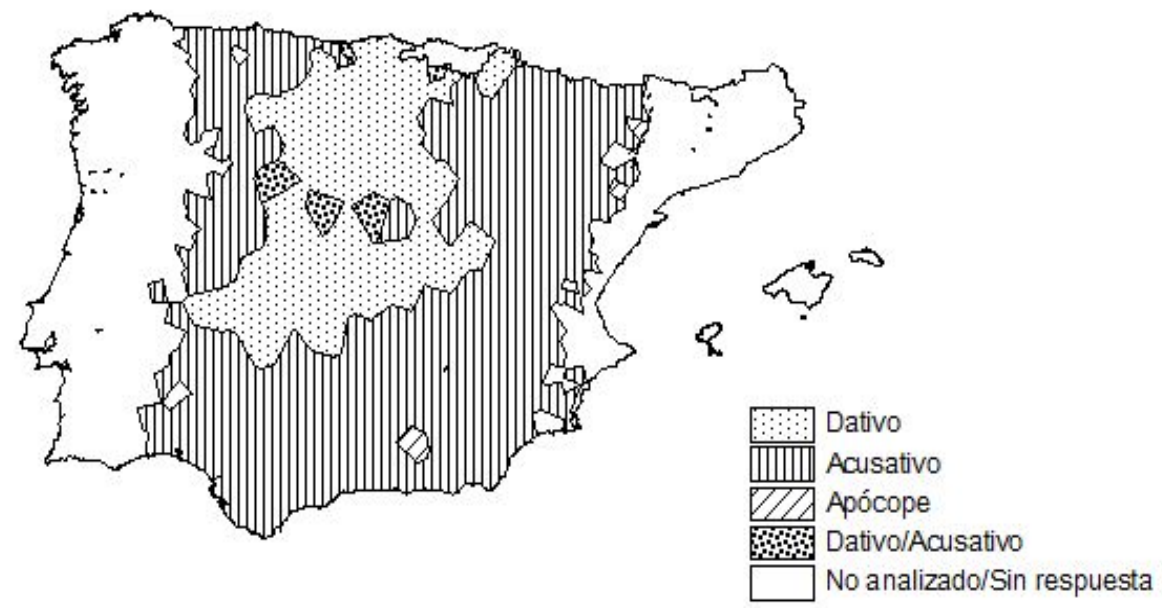

Map 2. A Miguel le cogieron preso 'Miguel was held prisoner'

Firstly, it is interesting to observe that this question of the questionnaire presents leismo for the masculine singular form: le [him.DAT.MASC.SG]. Although none of these phenomena of pronominal variation - leísmo, laísmo or loísmo - are considered correct, leísmo of person is even accepted by the Royal Spanish Academy, given its wide expansion. The use of le instead of $l o$ can be seen, apart from the referential areas, among the members of the society that enjoy the highest sociocultural level, since it is considered prestigious. However, a sentence like the one presented here should be constructed, according to the "etymological" criteria, with a pronoun in accusative: $A$ Miguel lo [him.AC.MASC.SG] cogieron preso.

The results exposed in the map agree with the proposal made by FernándezOrdóñez in the nineties. In the Peninsular north, all the Basque region and the northwest of Navarra present this type of leismo. Also in Cantabria the phenomenon is widespread, except in the western zone adjacent to the Asturias territory where leísmo 
does not exist because the masculine singular accusative pronoun is $l o$ or $l u$. In the Castilla y León community, leísmo is comprehensively identified in Palencia, Burgos, Valladolid, Ávila and Segovia and it also affects the eastern side of León and Salamanca and the west of Soria. Madrid is also a thoroughly referential territory but the data exposed in this map show an enclave, Valdepiélagos, in which the informant has chosen the accusative lo. Other areas affected by this phenomenon of pronominal variation are Toledo, the northwestern side of Ciudad Real, la Puebla de Don Rodrigo and Cuenca. Finally, it also spreads out through most of the Cáceres province, except a small strip in the northwestern side, and the northeast of Badajoz. Thus, the border between the territories, based on the distinction of the case and the ones that attend to referential patterns, is established. As can be seen, a coincidence is produced in relation to the results displayed by Fernández-Ordóñez (1994), without being complete because the phenomenon is also identified in Aliseda, according to the ALPI data, hence, exceeding the border established by Fernández-Ordoñez, who locates it between Plasencia and Trujillo.

Similarly, in several referential enclaves and others in contact with that area, the informants accept as correct the solutions with dative and accusative. That is what occurs in El Pego (Zamora), Hernansancho (Ávila), Rascafría (Madrid), Sarría (Álava) and Valle de Cabuérniga (Cantabria).

\subsection{Le llevaron a la cárcel 'He was taken to jail'}

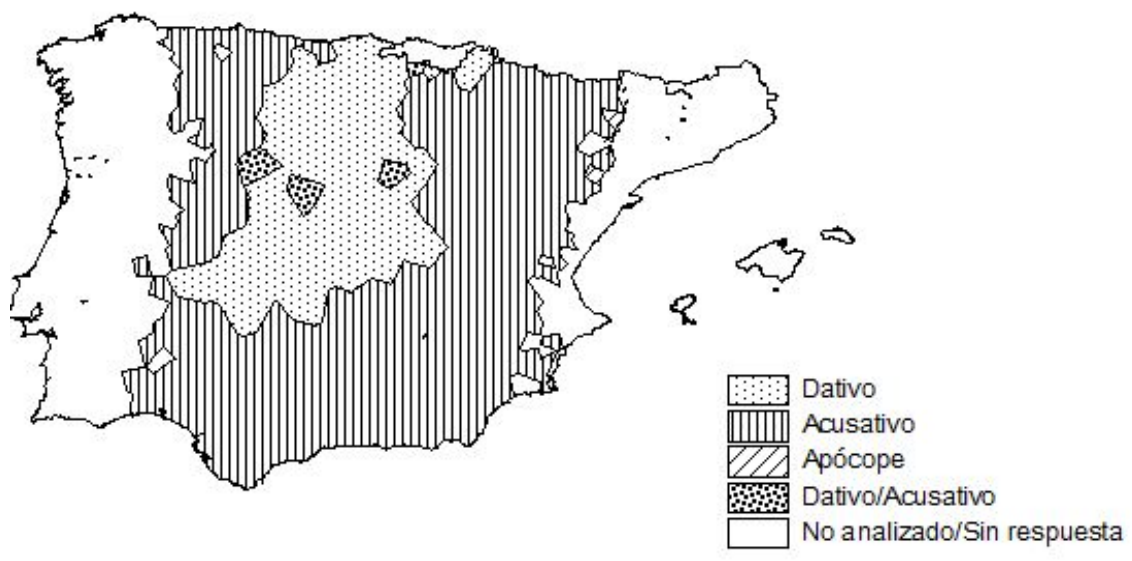

Map 3. Le llevaron a la cárcel 'He was taken to jail' 
This sentence presents characteristics very similar to the previous one. The mapped results show that, although the etymological use predominates, personal leismo presents a really broad expanse. In the distinguishing areas, the pronoun used by the speaker is the accusative, regardless of the fact that the question itself in the questionnaire encourages the use of the dative clitic. Since the speakers belong to rural areas and have a low educational level, it is expected that the standard influence does not manifest itself.

On the other hand, the selection of le for the masculine singular accusative is produced in the Castilian areas of Palencia, Burgos, Valladolid, Segovia, Ávila, west of Salamanca, east of Soria, in the whole Madrid community, in parts of Cáceres, in a small strip in the northeast of Badajoz and in Toledo, where the count/mass and gender distinctions are imposed over that of the case. This type of leismo is, in addition, typical in the Peninsular north, specifically in the Basque Country, Navarra and Cantabria. In fact, except in some Cantabrian zones, in which we can also observe some cases of laísmo in minority groups, leísmo is the only described phenomenon that is documented.

The map also shows how in certain localities the informants accept both the use of 10 and $l e$ for the personal masculine singular accusative. The territories in which this happens are Sarria (Álava), El Pego (Zamora), Hernansancho (Ávila) and Galbe de Sorbe (Guadalajara). All these villages are in contact with the referential zone, so it is not strange that this dichotomy in the pronominal uses is produced. Also, in Maella (Zaragoza) the loss of the final vowel does not permit to determine which third person unstressed pronoun is used.

\subsection{Al padre le vieron llorando 'The father was seen crying'}

Once again it is a sentence with similar characteristics to the previous ones. The peculiarity of this question, however, is located in the Cáceres area, because the leismo phenomenon described above has a lesser extent in comparison with the two previous sentences, closely resembling to the COSER data. Thus, the isogloss that separates the 
referential area from the etymological one, fully coincides with the proposal made by Fernández-Ordóñez (1993: 11). This line spreads, more or less, in a straight way, from the east of León to the northeast side of Badajoz. Then, between Toledo and Ciudad Real we find the strip that "divides the two sides of the Montes de Toledo". This isogloss goes up from Guadalajara to Soria separating the western part of both provinces. To this zone of pronominal variation should be added the current presence of the phenomenon in the Peninsular north, specifically in the Basque Country, Navarra and Cantabria, where it is completely widespread.

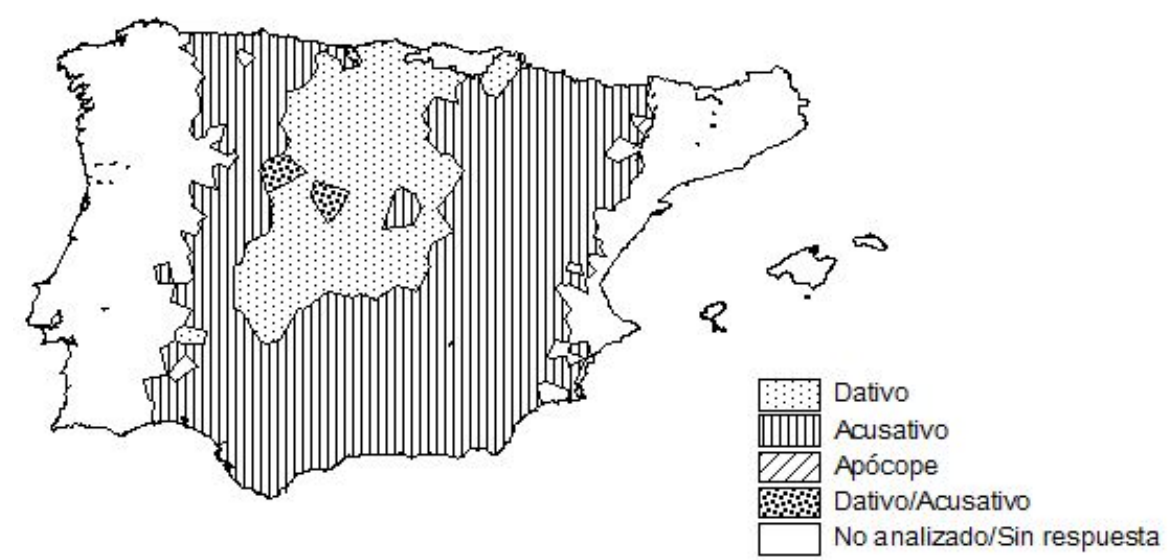

Map 4. Al padre le vieron Ilorando 'The father was seen crying'

In addition, there are two localities where the informants accept as their own the use of the accusative clitic as well as the dative one. These two places that manifest the duality coincide with the ones presented in the question Le llevaron a la cárcel: El Pego (Zamora) and Hernansancho (Ávila).

The rest of territories, as we can see, use the masculine accusative pronoun lo.

4.5 A los niños les socorrieron los vecinos 'The children were helped by the neighbors'

A los niños les socorrieron los vecinos is also a question that presents personal leísmo: les [them.DAT.MASC.PL]. However, it is a leísmo of masculine plural form, whose spreading is clearly inferior to that of the singular leismo because, only within the 
referential area, at least three solutions coexist: the use of the pronoun los [them.AC.MASC.PL] the use of the pronoun les or the use of both pronouns -although not in the same proportion- (Fernández-Ordóñez 1994: 93).

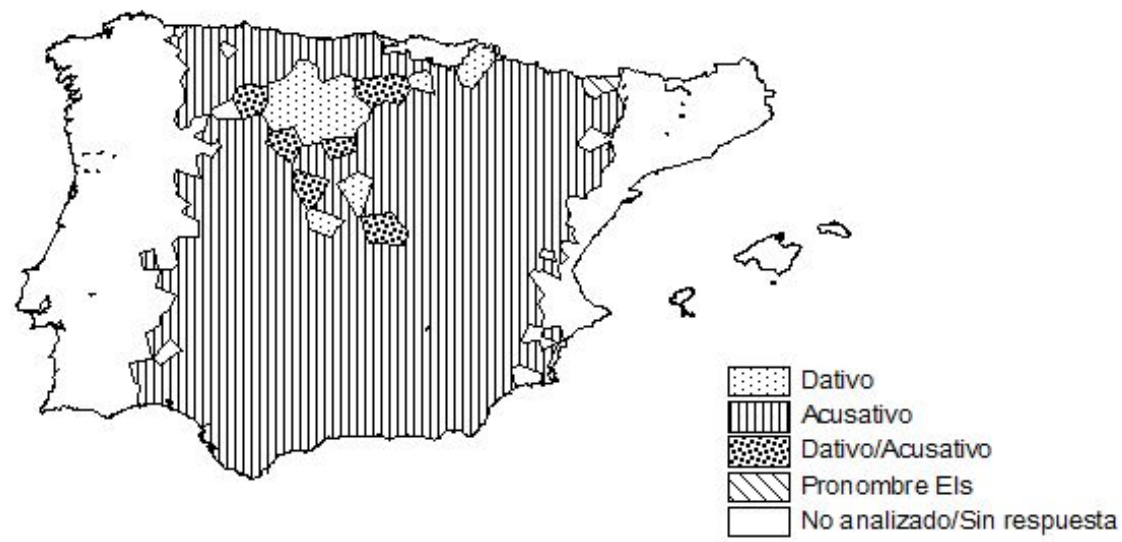

Map 5. Los niños les socorrieron los vecinos 'The children were helped by the neighbors'

According to the map, this type of leismo is produced in very limited areas: east of León province, all the Palencia province, west of Burgos and north of Valladolid. Furthermore, isolated territories where the informant has decided to use the dative unstressed pronoun instead of the accusative one are Goñi (Navarra), Cadalso de los Vidrios (Madrid), Rascafría (Madrid) and Treviño (east of Burgos). Otherwise, the rest of the localities use the accusative pronoun: as much within the limits of the referential system as in the areas considered distinguishing zones. ${ }^{7}$

Also, both solutions coexist in some enclaves: Laguna Dalga (León), San Cebrián de Mazote (Valladolid), Langayo (Valladolid), Valdelaguna (Madrid), Hernansancho (Ávila), Hontomín (Burgos), Vallarta de Bureba (Burgos) and Balbacienta (Cantabria).

In addition, in Manzanedo (Burgos), according to the notes of the interviewer, a second informant appears, who prefers the use of les, in spite of the fact that the first informant uses los in the map. This second informant, according to the notes presented in the upper half of the notebook, is more educated than the previous one. Then, it can

\footnotetext{
${ }^{7}$ Las Campas (Asturias) also uses les, but the verb offered in the questionnaire was replaced by another one that could have conditioned the answer of the informant: $a$ os nenos valironye sos vecius.
} 
be explained as an attempt to get closer to the standard system, which prefers the use of $l e(s)$ over $l o(s)$, given the prestige of personal leismo.

Therefore, it is a very interesting map because it shows how the results deriving from the analysis of the ALPI data mostly coincide with the investigations conducted by Fernández-Ordóñez in the nineties.

(In the northern area of the referential system (east of León, Palencia, northwest of Burgos, Valladolid) it is les. However, the southern zone prefers los (east of Salamanca, Ávila, east of Cáceres, west of Toledo and Madrid) . . . in some areas of the referential system of direct and indirect object (east and south of Burgos, south of Valladolid, north and center of Segovia, west of Soria) (FernándezOrdóñez 1999: 1362)

4.6 Me pidieron que les ayudase 'They asked me to help them'

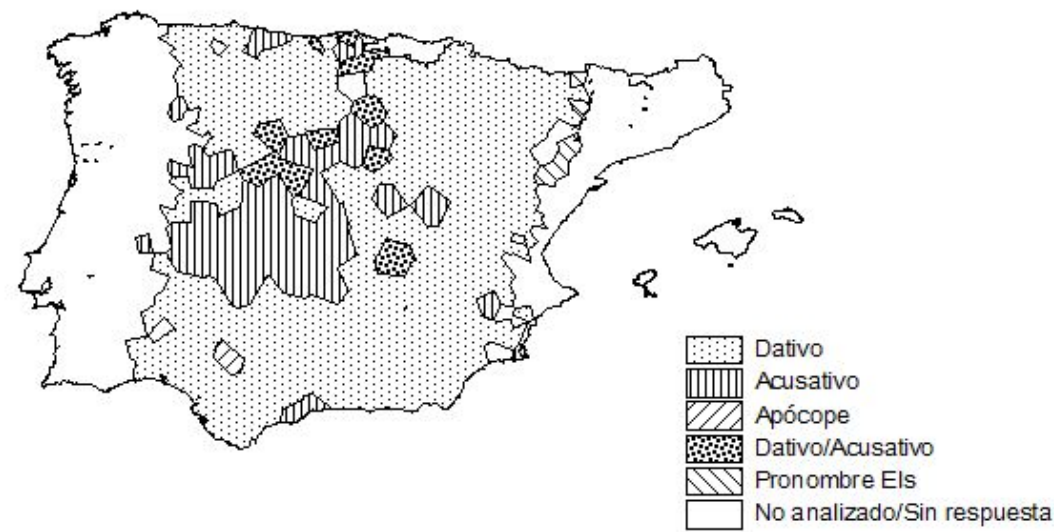

Map 6. Me pidieron que les ayudase 'They asked me to help them'

As in the sentence $A$ los niños les socorrieron los vecinos, this one, Me pidieron que les ayudase, has a third person plural clitic with a personal and animate referent. However, there are important differences between the two sentences: the verb socorrer 'to help' takes the accusative while the verb ayudar takes one or other case depending on the territory. Fernández-Ordóñez says that "we cannot relate the case variation of those types of verbs to structural or significant reasons". Furthermore, the author explains that this verb took the dative in the medieval language - along with verbs such 
as enseñar 'to teach', avisar 'to notify' or obedecer 'to obey' -, but it has become an accusative verb in some areas overtime (without specifying a precise moment). ${ }^{8}$

The data mapped from ALPI are close to the investigation carried out by Fernández-Ordóñez, but they suggest some modifications. Although the majority of case-distinguishing regions defend the usage of a dative clitic, there are other areas where participants preferred the accusative, for example in northeastern Salamanca and in a large part of Cáceres. ${ }^{9}$ Fernández-Ordóñez results are different from those shown in this paper for the west and south of Cáceres - where the usage of pronoun les would be expected. Instead, in the east area of Cáceres, the usage of pronoun los is expected because it follows the referential system. This new accusative interpretation of the verb ayudar appears in isolated zones of Málaga (Alhaurín el Grande and Olías), Murcia (Fuente de Pinos and Cabo de Palos), Cuenca (Albalate de las Nogueras), Asturias (Nozaleda) and Cantabria (Veguilla and Reconorio).

The referential area still selects the pronoun by its gender, number and mass/count categorization.

Referential patterns are also followed with plural referents, but the system (A) uses pronoun les with dative and accusative, while system (B) uses pronoun los for both cases. In the maps, these data confirm a preference for the pronoun los over les in Ávila, Segovia, southeastern Madrid, Toledo and Ciudad Real. In addition, western Soria and southern Burgos selected pronoun los, although these areas accept the use of both third person pronouns. Maybe, Valladolid presents the strangest situation within this referential area: although the usage of pronoun les as plural masculine dative and accusative is expected, ALPI data show that both uses can live together and some speakers can even use both pronominal forms.

Furthermore, Fernández-Ordóñez emphasizes that the verb ayudar could have changed the dative pronoun for the accusative in sentences of one complement and with feminine referents in the first place. The referent of the unstressed pronoun les is implicit in this sentence, but it is supposed to be masculine after analyzing previous

\footnotetext{
${ }^{8}$ See Fernández-Ordóñez (1999: 1330 and 2001)

${ }^{9}$ Participants used dative pronoun in Eljas, but the accusative pronoun in Ceclavín (south-east).
} 
phrases from the questionnaire. It can also be verified because all participants used the masculine pronoun los with the accusative instead of the feminine las.

According to the author, "prepositional transitivity" explains why the dative has been replaced by the accusative.

Some verbs like to help someone/somewhere demand, categorically, a preposition; others, like to obey (to), to be afraid (of), to warn (of), to teach (to), alternate the propositional regime with the direct one to express the inanimate object. Although to threaten (with/to) nowadays only admits the propositional regime, it can be included in this group because in the past it could also be constructed with two objects [...] Other verbs that can be affected by the same phenomenon are to inform (of), invite to, accuse (of), criticize (for), congratulate (for), of which a leista behavior is sometimes observed (Fernández-Ordóñez 1999: 1333-1334). ${ }^{10}$

However, the question does not allow to verify this theory because the verb complement is not given.

4.7 Al niño le pusieron un vestido 'The kid was made to wear a dress'

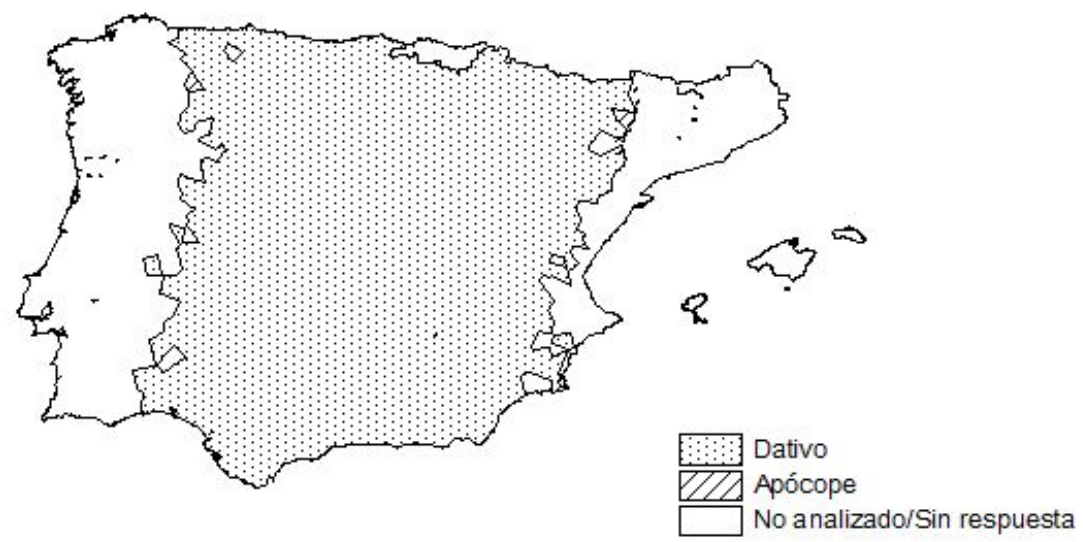

Map 7. Al niño le pusieron un vestido 'The kid was made to wear a dress'

\footnotetext{
${ }^{10}$ Complementary information about this issue can be found in Fernández-Ordóñez (2001).
} 
This sentence was included in the ALPI questionnaire to determine if there are cases of personal and singular loísmo in the Iberian Peninsula. Loísmo is the strangest pronominal variation phenomenon and it is the least developed because of its dialectal nature. Nevertheless, participants' unanimity is remarkable since none of them chose dative pronoun over the accusative.

This map coincides with the data collected by Fernández-Ordóñez.

4.8 Trae los candiles para echarles aceite 'Bring the oil lamps to oil them'

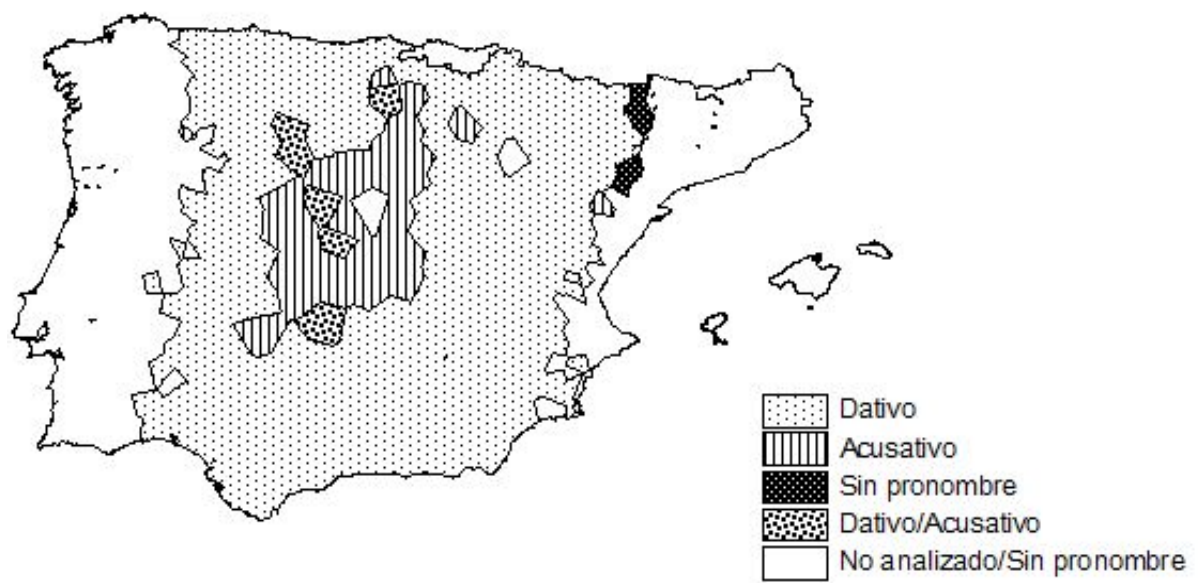

Map 8. Trae los candiles para echarles aceite 'Bring the oil lamps to oil them'

This sentence was given as an example in order to discover cases of plural loísmo.

The data mapped show that the use of accusative instead of dative appears principally in the referential territories, specifically in the east of Burgos, far west of Soria, Segovia, eastern Valladolid and Ávila. It also includes Madrid and Toledo, and the area expanding from the east of Cáceres and Campo de Peñaranda (Salamanca) to the northeast of Badajoz (Campanario).

After analyzing the areas of this phenomenon, it can be confirmed that speakers who preferred the usage of accusative pronoun los instead of dative pronoun les belong to the referential system. Thus, participants alternate pronominal forms to adapt them to the clitic selection criteria of the area. In this specific situation, those areas with a preference for the pronoun los over the pronoun les are the same as in FernándezOrdóñez $(1994,1999)$. 
Finally, there are several places where participants use both pronouns: Villacencio de los Caballeros (Valladolid), San Cebrián de Mazote (Valladolid), Hontomín (Burgos), Hernansancho (Ávila), Cadalso de los Vidrios (Madrid) and La Puebla de Don Rodrigo (Ciudad Real).

4.9 A la madre no le dieron la limosna 'The mother was given the alms'

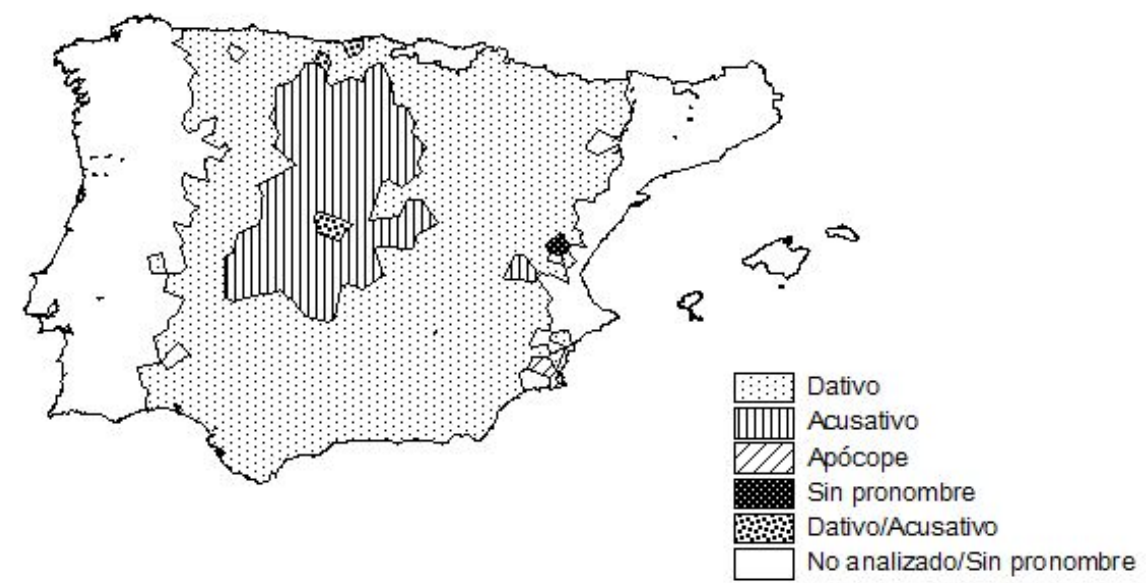

Map 9. A la madre no le dieron la limosna 'The mother was given the alms'

This sentence takes a ditransitive verb dar 'to give', which forms phrases with a direct object (Ia limosna 'the alms') and an indirect object (a la madre 'to the mother'). Also, a dative pronoun appears to double the first indirect object into the topic position.

As in the sentence $A$ ninguna le gusta ponerse la ropa de otra, the map shows two large areas based on the selected pronoun: the pronoun le is mainly used in the Iberian Peninsula and the pronoun la in some areas of Castilla y León and Castilla-La Mancha. Referential uses of these sentences are more extensive than A ninguna le gusta ponerse la ropa de otra because it also appears in Guadalajara (Renera) and Soria (Alcubilla del Marqués). In addition, they are extended to León (Calzada del Coto), Salamanca (Campo de Peñaranda) and Burgos (Manzanedo and Pinilla de los Moros); Madrid (Valdelaguna); Toledo (Los Yébenes); Ciudad Real (Puebla de Don Rodrigo); and Cáceres (Jarandilla). However, these results always agree with the area described by Fernández-Ordóñez (1999). 
Despite of being a case-distinguishing region, it is relevant that Caudete de las Fuentes (Valencia) uses the accusative case instead of the dative. The answers of the informant matches perfectly with the one given to another sentence of the questionnaire, A ninguna le agrada ponerse la ropa de otra. It is unclear what made him use the accusative clitic instead of the dative.

Along with these "etymological" and referential uses, it is noticed that informants accept the usage of both clitics in three more places: in Madrid (Cadalso de los Vidrios) and Cantabria (Yermo and Vega de Liébana). As this map shows, Cantabria does not present laísmo in general.

\subsection{Aquella desgracia le costó la vida 'That misfortune cost her her life'}

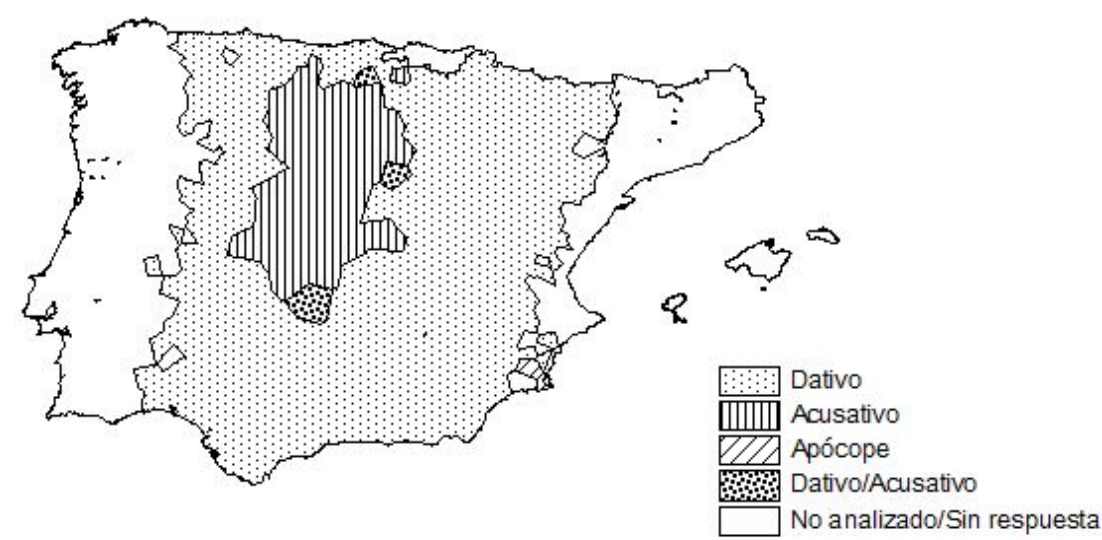

Map 10. Aquella desgracia le costó la vida 'That misfortune cost her her life'

Similar to the last sentences, Aquella desgracia le costó la vida includes the ditransitive verb costar 'to cost', which can take a direct object (la vida 'her life') and an indirect object (le). However, in this sentence the third person clitic does not double the indirect object. Although the referent is not specified, it is supposed to be la madre 'the mother' in the previous sentence 359. That explains why speakers from the referential area prefer the usage of accusative instead of dative.

Pronominal paradigm distribution is similar to $A$ la madre no le dieron la limosna. It verifies how much is the laísmo phenomenon spread: in Ávila, Segovia, Valladolid, Palencia, a large part of Burgos - except the north -, west of Soria, east of León, Salamanca and Cáceres. The usage of accusative instead of the "etymologic" use of 
dative appears in the entire territory of Madrid -except in the northeastern area where speakers prefer the dative -, and middle western Toledo.

In addition, there is just a village, Vega de Liébana (Cantabria), where the innovative solution is selected over the conservative one. Although there is hardly any laismo in this Community, informants may have chosen the accusative pronoun instead of the dative because they are next to Castilla y León. This phenomenon appears both in the sentences $A$ ninguna le gusta ponerse la ropa de otra and $A$ la madre no le dieron la limosna.

Finally, some participants accept both solutions -the "etymological" and the referential one- in Manzanedo (Burgos), Galbe de Sorbe (Guadalajara) and Puebla de Don Rodrigo (Ciudad Real), near to the referential zone.

4.11 A las hermanas les entregaron unas cartas 'The sisters were delivered some letters'

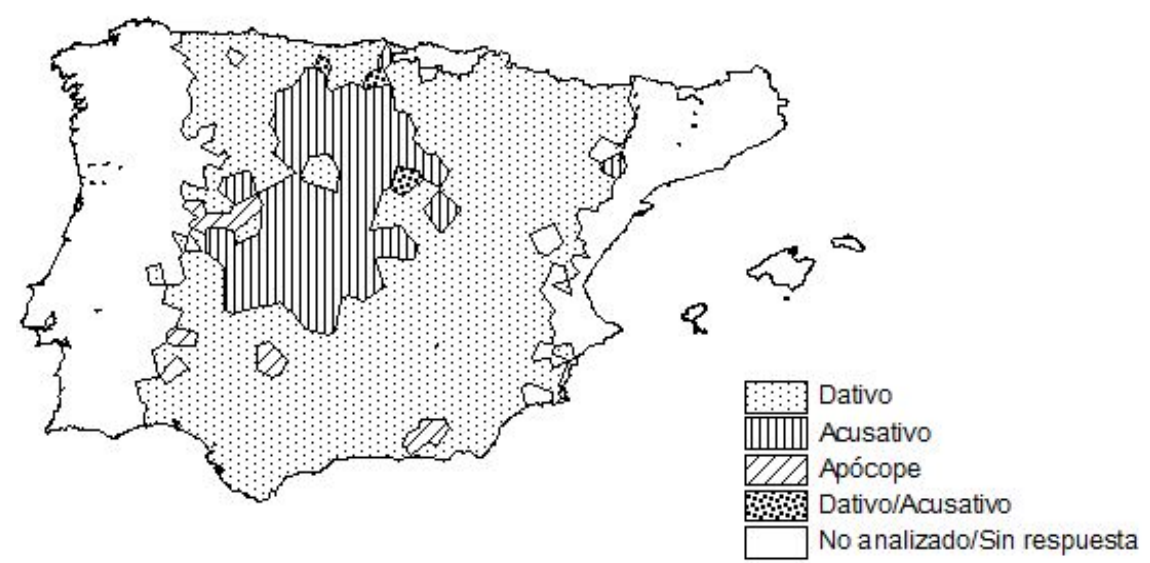

Map 11. A las hermanas les entregaron unas cartas 'The sisters were delivered some letters'

This sentence is used to analyze the plural laísmo phenomenon. As it happens with singular, selection of unstressed pronoun based on gender is generalized in Palencia, Valladolid, Segovia, Ávila and Burgos; also in a large part of Salamanca, the east of León and western Soria. The extension of the plural laismo phenomenon is the same as the singular one in Madrid, as in the phrase Aquella desgracia le costó la vida. The substitution of dative for accusative is also seen in the middle west of Toledo, in northwestern Ciudad Real - concretely in Puebla de Don Rodrigo - and in Gárgoles de Abajo (Guadalajara). 
Two ideas are deduced from this map. Firstly, laismo in Cáceres - from north to south and middle western areas (Pinofranqueado) is more extended than in the former sentences. And secondly, there is not a complete equivalence with the results of Fernández-Ordóñez. Again, western Cáceres has more referential uses in ALPI than in COSER.

4.12 No lo vacies en la calle 'Don't empty it into the street'

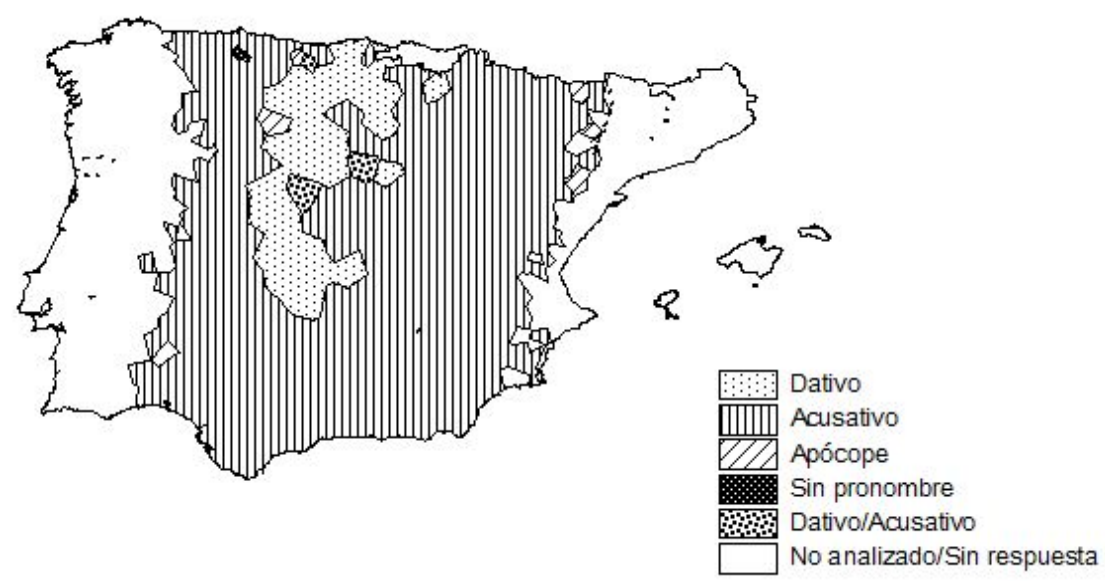

Map 12. No lo vacies en la calle 'Don't empty it into the street'

No lo vacies en la calle is closely related to its previous question ¿Dónde vacían el cántaro? 'Where do they empty the pitcher?' Thus, the nominal phrase el cántaro 'the pitcher MASC is the referent of the unstressed third person pronoun lo in sentence 312.

Inanimate leísmo is identified with this sentence because the verb vaciar to empty' is transitive and it takes accusative. ${ }^{11}$

The field of influence for inanimate singular masculine leismo is smaller than personal singular masculine leísmo, although it also affects areas of the north and center of the Iberian Peninsula. The usage of the dative pronoun is preferred in middle eastern Cantabria, Palencia, north central Burgos, Valladolid, middle northeastern Segovia, the east corner of Salamanca, Ávila, middle western Toledo and Puebla de Don Rodrigo (Ciudad Real). ${ }^{12}$

\footnotetext{
${ }^{11}$ This question was related to the verb vaciar in the beginning, but it also helps in the study of inanimate masculine singular leismo since it is the only sentence analyzing this pronominal variation within ALPI.

${ }^{12}$ In Valle de Santa Ana (Badajoz), the first informant uses the accusative pronoun and the second one prefers the dative pronoun.
} 
The border between the referential area and the case-distinguishing region in northwestern Castilla is the same as the map of personal singular masculine leísmo - being Montes de Toledo the border itself However, there are important differences in the eastern referential area because it does not show inanimate leísmo - , although those territories showed animate leísmo in sentences like A Miguel le cogieron preso, Le Ilevaron a la cárcel or Al padre le vieron llorando. For example, Madrid does not have inanimate leísmo, but it is completely referential for other uses. Whereas it is normal not to have this leísmo type in the west of Soria, which is a transitional area, - more cases would be expected in Segovia and Burgos.

In some village, informants used the accusative case with a feminine referent, such in No la vacíes en la calle, like in Alloza (Teruel) or Linares de Riofrío (Salamanca). Other three villages - Valle de Liébana (Cantabria), Hernansancho (Ávila) and Barbolla (Segovia) - accept accusative and dative pronouns for the same referent. In Yermo (Cantabria), two participants answered using different antecedents: the first one talks about el caldero - No lo vacies en la calle - and the second one talks about la comida 'the food', so he uses the feminine accusative - No la vacies en la calle.

Cenera (Asturias) is the only place with the absence of unstressed pronoun: No tires en la calle 'Do not throw it in the street'; some participants used an apocope and it is impossible to identify any pronoun. A large part of territories with shorten clitic cohabit with Catalan and Aragonese by adopting the pronominal uses of those languages. For example, No'l vacies al carrer was the answer in San Esteve de Llitera (Huesca); the vowel apheresis makes sense with a third person clitic el 'it', such as in Catalan, but not with le or lo pronouns.

\section{Discussion}

\subsection{Leísmo}

In order to define which area has personal masculine leísmo (singular and plural), the following sentences were used: A Miguel le cogieron preso, Le llevaron a la cárcel, Al 
padre le vieron llorando and A los niños les socorrieron los vecinos. In this paper, I have corroborated the proposal of Fernández-Ordóñez about a larger spread of singular leismo instead of the plural one because the referential territory uses both unstressed third person pronouns in plural (les and los). Furthermore, the Royal Spanish Academy accepts the usage of personal singular masculine leismo and speakers with a high level of education use pronoun le as a singular accusative clitic inside and even outside the referential area - but of course this type of informant does not appear in ALPI.

As it can be seen in the maps, singular masculine leismo has a compact development in the referential and Basque zones - including speakers with a high level of education (not represented in the maps); plural masculine leismo appears in northwestern Castilla y León and in some isolated localities, like in central and northern parts of the Iberian Peninsula. The maps presented above about personal plural masculine leísmo, as in the sentence $A$ los niños les socorrieron los vecinos, show the same geographic distribution as those proposed by Fernández-Ordóñez.

It is important to point out that there were more sentences of personal singular masculine leísmo than plural leísmo, so results will be more reliable in the first type. The maps for singular leísmo are very similar, but not identical. This type of leísmo is generalized in País Vasco (Álava and Vizcaya), Navarra, Castilla y León (Burgos, Palencia, Valladolid and Segovia) and Madrid. The border of transition between casedistinguishing regions and not distinguishing regions is the same: the leísmo phenomenon appears in the east corner of León and Salamanca, western Castilla y León, and western Soria. This proposal slightly disagrees with the mapped results of the sentence A Miguel le cogieron preso because this shows leísmo in several places of León normally belonging to the case-distinguishing region.

There are other differences among maps in the southeastern area - a transitional area: some of them show this phenomenon only in far northwestern Toledo while others placed it across the whole province until Ciudad Real. The leísmo isogloss changes in Extremadura depending on the sentence. For example, A Miguel le cogieron preso or Le llevaron a la cárcel present leísmo in southwestern Cáceres, but not Al padre le vieron Ilorando. COSER data limit personal singular masculine leismo to the east of Cáceres (including Plasencia and Trujillo, as it was mentioned before), precisely, such as in the 
sentence Al padre le vieron llorando in ALPI. It is not clear why the other two sentences have different results (extending the area to Aliseda in Cáceres). Perhaps, one of the reasons is the verbs: ver, which is a stative verb, while coger and llevar are dynamic verbs. However, in some analysis (García 1975), stative verbs are supposed to favor leismo, which disagrees with the results of this paper. Other reasons might be that the input questions made to informants included leísmo, and that the methodology to obtain answers could have influenced the answers. Nonetheless, it is a weak argument since it should be proven in other answers and areas. The discrepancy could be perhaps explained by an unrepresentative selection of the informant in Aliseda.

In conclusion, according to the data collected from all the sentences of the questionnaire, the borders of this personal leismo are the same both in ALPI and in COSER for the northeastern and northwestern areas, but not for the southwestern one.

In addition, inanimate leísmo (or leísmo of "thing") has been analyzed. As it was mentioned before, the referential system chooses unstressed third person pronouns based on a mass/count distinction: the pronoun le is used with masculine count referents and the pronoun lo with mass ones. Therefore, the inanimate leísmo distribution area could be equivalent to the one with personal singular masculine leísmo within the referential territory, where the clitic le is expected with count referents (and so are people).

The analysis of the sentence No lo vacies en la calle - with cántaro as antecedent in ¿Dónde está el cántaro? - shows a match between the area of pronominal syncretism and the one proposed by Fernández-Ordóñez. The only exception is the transitional eastern zone where leísmo is less noticed in ALPI than in COSER. Regarding that, it could be thought that a spreading of leismo might have happened during the 20th century. Nevertheless, it has to be pointed out that leismo in the east of the referential area is not as regular as in the west, not even in the COSER data.

\subsection{Laísmo}

In order to study the phenomenon of singular laísmo, the following sentences have been used: A ninguna le gusta ponerse la ropa de otra, A la madre no le dieron la 
limosna and Aquella desgracia le costó la vida. Plural laísmo is studied with $A$ las hermanas les entregaron unas cartas.

As it is shown above, the three sentences of singular laismo are not entirely similar. On one side, A la madre no le dieron la limosna has a personal subject and it is a ditransitive sentence. On the other side, Aquella desgracia le costó la vida has an inanimate subject and $A$ ninguna le gusta ponerse la ropa de otra has an infinitive phrase placed as subject. These last two sentences present verbs of psychological affection; it means that whoever experiments the verb action is placed in the dative case position. Despite of the syntactic differences with the type of indirect object or the verb, all of them present typical characteristics of the laismo phenomenon and its geographic distribution throughout the Iberian Peninsula is very similar in all the sentences of the questionnaire.

As it can be seen in maps 1, 9-10, the referential area includes territories from eastern León to far northeastern Badajoz on the western side, it reaches the west of Soria on the eastern side and, in the southeastern side, The Montes de Toledo. This area mostly coincides with the research of Fernández-Ordóñez. The most important difference appears in Cáceres where plural laísmo is occasionally presented as it was shown with personal singular leísmo. In Fernández-Ordóñez's survey, only eastern Cáceres belongs to the referential area.

The distribution of plural laísmo is researched with the sentence $A$ las hermanas les enviaron unas cartas and it is very close to the allocation of singular laismo shown in the sentence $A$ la madre no le dieron la limosna. Both of them are ditransitive phrases with animate subjects. The same development of plural and singular laísmo is expected because there is only one feminine pronoun $(I a(s))$, unlike what happens with leísmo with two masculine pronouns available, les / los. The unstressed third person clitic for a plural masculine referent can be both the pronoun los and les, but only the pronoun le is used with a singular count masculine referent (within the referential area).

This type of plural laísmo affects a large zone of Cáceres and, as said before, the distribution disagrees again with the study carried out by Fernández-Ordóñez. Perhaps, it could be due to an unrepresentative selection of the informants or the methodology applied. Nevertheless, it is difficult to accept this idea since laísmo should not have been 
documented unless used with regularity, unlike personal leismo, which is a prestigious usage and appears on the questions.

\subsection{Loísmo}

Loísmo of personal singular masculine referents was analyzed with only a question - Al niño le pusieron un vestido - and it confirms the conclusion of Fernández-Ordóñez about a nearly absence of this phenomenon in the Iberian Peninsula

Me pidieron que les ayudase has been used to study personal and plural loísmo. The majority of the case-distinguishing regions use the dative pronoun les, but the referential area prefers the pronoun los in its central and southern territories - according to what is used in referential system areas B and C. Again, this ALPI sentence offers different results than those obtained by COSER in Cáceres. The usage of the pronoun les was expected in the west and south of Cáceres while the clitic los would appear in the east (i.e. the referential area). Only eastern Cáceres meets the expectations. In addition, some informants in the referential area of Valladolid used the pronoun les whereas others opted for an unexpected pronoun, los.

Nevertheless, it has to be pointed out that verb types can affect these results. As it was mentioned before, the verb ayudar takes dative or accusative depending on the territory and it favors the pronominal variation. Other case-distinguishing regions tend to make this verb transitive by using the pronoun los, like Asturias, Cantabria, Cuenca, Málaga and Murcia. Thus, this phenomenon cannot be interpreted in these provinces as true loísmo.

The sentence Trae los candiles para echarles aceite helps to analyze plural loísmo with an inanimate referent. The data mapped have shown that this phenomenon is restricted to the referential area. 


\section{Conclusions}

This paper has studied the distribution of unstressed third person pronouns in Spanish using the ALPI data, but not including Catalan and Galician-Portuguese areas. After having mapped this information, I have carried out a comparative analysis between results from 1930s and those collected in the 1990s by Fernández-Ordóñez. Therefore, I have come to the conclusions appearing below.

The collected results from the ALPI data about pronominal variation phenomena - leísmo, laísmo and loísmo - have shown a stable geographical distribution in the Iberian Peninsula during the 20th century. There are isoglosses in the above mentioned territories that separate the case-distinguishing regions - in which an "etymological" or case-based pronoun system has remained - from the referential areas which have systems affected by referential or semantic principles.

Only two of my results have disagreed with the COSER data. On the one hand, the geographical spreading of leísmo, laísmo and loísmo in Cáceres is not the same as in the COSER results, because they tend to extend the area. On the other hand, inanimate leismo, which has been studied with the sentence No lo vacies en la calle, has proved a larger area in the 1990s survey than in the 1930s. Fewer cases than expected have been documented for this leísmo in Burgos, Segovia, western Soria and Sierra de Madrid, despite of being transition areas in which the appearance of this phenomenon is not completely regular. Probably, this conclusion is not totally sound and it could change if there had been more questions included in the questionnaire for the study of such leismo. Nevertheless, this result sets out a rising of leísmo within the referential area throughout the 20th century.

Finally, it seems that laismo is not conditioned by the type of indirect object or the sentence structure. The isogloss between referential territories and case-distinguishing regions is almost the same in all answers. The results have not been noticeable for the type of subject (animate or inanimate) or the number of verb arguments. However, these are important elements, because the clitic selection can change in sentences with the same verb depending on the type of subject, object or characteristics of the verb, as proven, for example, with the verb ayudar. 
Using an artificial geolinguistics questionnaire did not affect too much the documentation of these phenomena once established in the regional language. Nonetheless, in transition areas, where speakers use both accusative and dative forms for the same linguistic structure, the methodology presents problems to register all the competing forms. That could be the explanation for the lack of inanimate leismo in ALPI in the east and south of the referential zone.

\section{References}

FernándeZ-ORdóÑEZ, Inés (1993) "Leísmo, laísmo y loísmo: estado de la cuestión", in O. Fernández Soriano (ed.), Los pronombres átonos, Madrid: Taurus, 63-96.

FeRNÁNDEZ-ORDóÑEZ, Inés (1994) "Isoglosas internas del castellano. El sistema referencial del pronombre átono de tercera persona", Revista de Filología Española, LXXIV, 71-125.

Fernández-Ordóñez, Inés (1999) "Leísmo, Laísmo y Loísmo", in I. Bosque / V. Demonte (dirs.), Gramática Descriptiva de la Lengua Española, 3 T., Madrid: Espasa-Calpe, T. 1, cap. 21, 1317-1397.

FERNÁNDEZ-ORDÓÑEZ, Inés (2001) “Hacia una dialectología histórica. Reflexiones sobre la historia del leísmo, el laísmo y el loísmo", Boletín de la Real Academia Española, LXXXI, 389-464.

García, Erica C. (1975) The Role of Theory in Linguistic Analysis. The Spanish Pronoun System, Amsterdam: North-Holland Linguistic Series, 19.

García Mouton, Pilar (2009) "Justificación metodológica de un atlas lingüístico para el castellano del centro de España", Estudis romànics, 31, 263-266,

Gómez Seibane, Sara (2012) Los pronombres átonos (le, la, lo) en el español, Madrid: Arco/Libros.

HEAP, David (2003) ALPI online <Publicación electrónica en http://www.alpi.ca>.

KLein-Andreu, Flora (1981) "Distintos sistemas de empleo de le, la, lo. Perspectiva sincrónica, diacrónica y sociolingüística", Thesaurus, XXXVI, 284-304 (Reprinted in O. Fernández Soriano (ed.), Los pronombres átonos, Madrid: Taurus, 1993, 337-353).

KLEIN-ANDREU, Flora (2000) Variación actual y evolución histórica: los clíticos le(s), la(s) y lo(s), München: Lincom Europa.

Navarro Tomás, Tomás (1962) Atlas lingüístico de la Península lbérica, Vol. 1. Fonética, Madrid: Consejo Superior de Investigaciones Científicas. 
ROSÉS LABRADA, Jorge Emilio (2012) "Variation in third-person objet pronouns in Zamora province Spanish, according to ALPI data", Dialectología, special issue III, 157-176. <http://www.publicacions.ub.edu/revistes/dialectologiaSP2012/> 